\title{
"Some Punishment Should be Devised": Parents, Children, And the State in VICTORIAN LONDON
}

The uncultivated cannot be competent judges of cultivation. Those who most need to be made wiser and better, usually desire it the least, and if they desired it, would be incapable of finding the way to it by their own lights.

— John Stuart Mill, Principles of Political Economy (1848)

What any of us does in our own lives is a private matter-a precious and inalienable right. But once we enter the job market or national and local authority domains, or tread into places where there is interaction with different citizens, privacy and individual choice become contested-quite rightly, for there is such a thing as British society.

- Yasmin Alibhai-Brown, British columnist (2006) ${ }^{1}$

To historians of nineteenth-century Britain, contemporary debates over the boundaries between personal liberty, government authority, and the public good have a familiar ring. In his 1937 retrospective, Thomas Gautrey, a former member of the School Board for London (the "LSB" or "London School Board," as it was commonly called), recalled how widespread opposition to government interference in working-class home life had crippled the board's ability to educate the children of Victorian London. The LSB, he declared sorrowfully, had been "a beneficent giant - working in chains." 2 The elected officials of the LSB had been responsible for managing the elementary schools of the metropolis since the passing of the Education Act of 1870 (a.k.a. "The Forster Act"), which had established the foundations of England's first public elementary education system. ${ }^{3}$ Gautrey's recollection was a part of the broader comparison he drew between the LSB and the London County Council (LCC), the elected municipal body that had assumed overall control of London's state elementary schools with the dissolution of the 
LSB in 1904. In his remembrances, the LCC did not fare well in comparison to its predecessor. The LCC was calculating and aloof from the needs of London's poor, whereas the LSB had been a "noble" endeavor, motivated by compassion and philanthropic ideals, and dedicated to the goal of educating the children of London's laboring classes. ${ }^{4}$ The most significant obstacles that the LSB faced in this task, according to Gautrey, were "ignorant and unscrupulous parents" and "the three great enemies to battle with: illiteracy, bad manners, and dirt."5

Gautrey's praise of the LSB, however, was strongly colored by nostalgia. In the decades following its inception, parents and school officials clashed ceaselessly over the boards's decision to compel parents to send their children to school. From 1887-1903, at the behest of LSB officials, London's courts of summary justice issued 275,255 convictions to parents for neglecting to educate their children in accordance with the law. ${ }^{6}$ The number of parents LSB officials interviewed in more informal settings, such as the streets of working-class communities or the weekly meetings of the local school attendance committees, was many times that number. In the same sixteen-year period, the LSB issued 1,589,498 "Notices B" demanding that parents meet with a tribunal of school officials to explain why they had disobeyed the compulsory attendance laws. ${ }^{7}$ During its quarter-century lifespan, the LSB and its agents were the objects of considerable criticism and opposition, both public and private. Hostility against the board ranged from angry newspaper editorials to direct physical assault on its agents, the School Attendance Officers. ${ }^{8}$ Opposition to the LSB's policies came primarily from other middle-class reformers who disagreed with the Board's methods and from workingclass parents who openly defied efforts to compel their children's attendance at school. 
The principles and methods of educational compulsion were so adamantly opposed by one critic, Ernest Pomeroy, that in 1909, half a decade after the dissolution of the LSB itself, he published a comprehensive guide for those who wished to evade the laws that the LSB had left as part of its contested legacy. The guide's title, The Education Tyranny: The Education System Examined and Exposed, Together with Practical Aids for Persecuted Parents, left little doubt of the author's views on compulsion. ${ }^{9}$

Pomeroy's title highlighted the deeper significance of the arguments that took place over the England's adoption of compulsory school attendance for its children. ${ }^{10}$ First, the use of the phrase "tyranny" was not accidental. Much of the opposition to compulsory education was linked to broader political concerns over the intrusion of the state into private life and the threat to the ideal of liberty that such intrusion represented. Compulsory education, as a contested and often unpopular policy, represented a particularly fruitful avenue of attack for those who opposed the expansion of the state into day-to-day life. Second, although the laws on compulsory education ostensibly concerned working-class children, Pomeroy's book, like the laws themselves, was aimed primarily at working-class parents.

Drawing on the public debates surrounding the adoption and practice of compulsory education in London, this article makes two related arguments. The first is that compulsory school attendance was a phenomenon distinct in both theory and practice from the actual schooling of working-class children. This stance contradicts traditional approaches to compulsory education, which have treated compulsion and schooling as one and the same. ${ }^{11}$ The Education Act itself permitted the local adoption of compulsory attendance laws but did not require them, leaving the decision up to elected school 
boards. At all but the highest level of governance, the laws, dynamics, and actors involved in the enforcement of compulsion were different from those that determined curriculum or governed the instruction of children. The work of compulsion took place in working-class neighborhoods, at attendance committee tribunals, and in the law courts. Compulsion did not cross the threshold of the schoolroom and teachers themselves played no official role in the process aside from recording children's attendance and absence. Merging compulsory attendance and schooling is analogous to conflating military conscription with military training, and few would argue that being drafted is the same as training to become a soldier.

Secondly, I argue here that the London School Board's decision to adopt laws compelling children to attend school was directed at working-class parents more so than at their children and, as far as LSB members were concerned, schooling for the latter was seen largely as an amelioration for the moral failings of the former. In essence, the laws on compulsory school attendance mandated the replacement of parents with the state as the primary authority in determining the schedule of working-class children's lives. These new laws on education thus redefined the relationship between working-class parents and the state in Victorian London, paving the way for national and local government to take a more active role in the direct regulation of working-class home life than it ever had before. ${ }^{12}$ As much as the Education Act of 1870 was a watershed in the history of English social reform, the decision by the London School Board to adopt compulsory education in 1871 also represented a milestone in the evolution of the British interventionist state. 
Examining the London's School Board's adoption of a compulsory school attendance policy also provides a number of useful insights into broader trends of social and political development in Victorian England. Along with housing and health reform, the implementation of universal, compulsory education was one of the most important and extensive projects of social reform to take place in the second half of the nineteenth century. The issue of compulsory education was also intertwined with the legal and cultural construction of childhood in nineteenth-century England. ${ }^{13}$ The laws on compulsory education, moreover, were among the first statutes that brought the reach of public authority and its agents into the working-class home on a daily basis. As such, they became a central subject in the larger debate over the expanding role of the state in private life. Those who supported compulsory attendance would claim that such state interference in working-class home life was necessary for the good of working-class children and the moral health of the home as a whole. ${ }^{14}$ Educational reformers and many members of the LSB alike were confident that their moral authority and their understanding of working-class life qualified them as better judges than working-class parents themselves were of what was good for their children and for their families as a whole. One of the central justifications for state intervention, which would appear again and again in the arguments for compulsory education, was that working-class parents had little emotional attachment to their children and were indifferent to their health and wellbeing. ${ }^{15}$

The implementation of compulsory education was preceded by other measures of significant social reform - in particular the laws on public health - but such a level of continual involvement and interference in the day-to-day lives of working-class parents 
and children was heretofore unknown. ${ }^{16}$ Not a once-only demand like compulsory vaccination or a set of statutory limitations like the housing code, the compulsory attendance laws insisted upon parents' daily adherence to an inflexible timetable determined by the local educational authorities. The LSB occupied the top tier of the mechanism of educational compulsion in the social, economic, and political center of Britain. The attitudes of its members towards this considerable alteration in the daily lives of working-class Londoners were essential in setting a precedent for the role that the state would take in private life in subsequent decades.

The public contests over compulsion, intertwined as they were with parents' relationship to the state, the role of the government in everyday life, and contesting notions of individual freedom versus collective good, revealed the challenges posed to Liberal ideology and policies by the growing threat of international competition. ${ }^{17}$ The debates also helped articulate a concept of popular citizenship that was defined by the duties of the citizen to the nation rather than by the liberty of the individual against the intrusion of official authority, a concept that was increasingly being embraced not only by middle-class reformers but also by working-class Trade Unionists. ${ }^{18}$ The decision to adopt compulsion was an attempt by national and local policymakers to train both parents and children to be responsible members of the national community, and to inculcate in them the notion that loyal members of this community would demonstrate their commitment by obedience to its formal policies. These policies, according to lawmakers, had been adopted for the good of the nation, and therefore adhrerence to them constituted a sacrifice that implicitly brought the poorest of the working-class within the boundaries of a national community from which middle and upper-class commentators had excluded 
them in the past. ${ }^{19}$ The imposition of compulsory education policies thus represented a substantial step towards forging this new ideal of mass participatory citizenship, an ideal that would reach its fullest expression with the contested imposition of compulsory military service in Britain during the First World War.

$$
\text { *** }
$$

The debate over compulsory education long preceded the passing of the 1870 Education Act. One of the most lucid and comprehensive arguments put forward in favor of compulsory education was found in a short book written by Frederick Timbrell, an administrator for St. Stephen's, a prestigious private school in Westminster. ${ }^{20}$ Writing in 1855 , Timbrell articulated several essential arguments for compulsory education that would later be echoed by members of the LSB and their contemporaries. Timbrell discussed the connection between children's labor and education, described the selfishness and ignorance of working-class parents, and argued that any move towards compulsory schooling would be met with strong opposition from both parents and employers. He concluded that only the sternest measures would force children to leave the workplace and bring them into the schoolhouse.

Timbrell's main argument concerned the deleterious effects of children's labor on their intellectual progress and on their preparation to become contributing members of the national community. "It is, above all else," he wrote, "the cause of the shameful ignorance of the youthful poor, the citizens and people of our future. We speak of the use of juvenile labour, the employment of children by parents, tradesmen, or, worse than all, 
in mines and factories." ${ }^{21}$ This focus reflected the broader humanitarian opposition to children's labor that had been growing since the 1830s and would continue unabated throughout most of the nineteenth century. ${ }^{22}$ "This [children's employment]," he insisted, "can never exist in any but the most emphatically unnatural system of education. ${ }^{, 23}$ For Timbrell, the primary purpose of compulsory schooling was not simply to educate the poor, but rather to counter the perceived social evil of children's labor and its deleterious effects on the preparation of children for future citizenship. In essence, Timbrell was arguing for a reconstitution of the role of working-class children more in line with contemporary middle-class ideals of childhood and with a view towards their potential contributions to the nation. ${ }^{24}$

This ideal, the child as schoolchild and future citizen rather than as mean laborer, stood in stark contrast to Timbrell's assessment of working-class parents' views on the role of their children. According to him, "the use or profit of the labour of children by parents, or those responsible for their support . . is looked upon by the vast majority of all classes, by almost all of the labouring poor, as an unquestionable right." ${ }^{25}$ The actual quality and content of the education working-class children would receive were not an issue here. The goal, argued Timbrell, was to use compulsory schooling as a means to rescue children from the workplace and from the parental avarice that kept them there. Timbrell cynically portrayed working-class parents as being concerned only with children's economic contributions and as being entirely indifferent to their own parental obligations. "In the ethics of the labouring classes," he wrote, "the duties of the child in relation to the parent are looked upon as of vastly more consideration than, that which is becoming nothing more than a moral notion, the existence of similar duties in the 
parent." 26 Here, Timbrell articulated what would become, in the coming decades, the basic justification for the interference of the state and voluntary authority in the workingclass home. Working-class parents were selfish and immoral, he argued, and it was the duty of the State to protect children from exploitation and neglect. ${ }^{27}$ This argument for the State as the protector of working-class children was based on the assumed moral superiority of the agents of reform and was as much anti-parent as it was pro-child. ${ }^{28}$ In the face of parental neglect and failure, Timbrell felt the responsibility of the State was clear. "Wherever the lowest form of parental duty," he wrote, "the mere support of life, is unexercised either from necessity or neglect, there the State at once takes upon itself, or compels the performance, of the duty." 29

For all of his criticism of working-class parents, however, Timbrell stopped short of suggesting direct compulsion. Rather than advocating the imposition of fines to enforce school attendance, he instead suggested that the state enact a national standard linking children's eligibility for employment to their age and level of education. Echoing the words of one of Her Majesty's Inspectors of Schools, Timbrell insisted that "some punishment should be devised for the uneducated." 30 He admitted that a rewards-based system might indeed be "less repulsive," but provided further support for harsh measures with an explicit reference to the hallowed father of Liberalism. "The withholding of political, civil, or commercial privileges from the uneducated as a means for the compulsory acquirement of school knowledge, as, in fact, a punishment for willful ignorance has no claim to novelty," Timbrell wrote, "it was proposed years ago, by Adam Smith."31 Timbrell argued that the best way to secure school attendance was to impose an absolute moratorium on children's employment until the age of thirteen, and a partial 
restriction on such employment from the ages of thirteen to fifteen "unless [they were] furnished with a certificate proficiency in the essentials of education." ${ }^{32}$ With the imposition of such laws, he asserted, "even in the absence of direct compulsory measures upon the parents, they, unable to employ their children before thirteen, would use their best endeavours and means to qualify them for work at thirteen, if only from mercenary motives." ${ }^{33}$ Timbrell's arguments demonstrated the degree to which the initial debate over compulsory education tended to focus much more on the habits and character of working-class parents than on the children themselves. The growth of the child-welfare movement in 1880s would change this situation somewhat, but concern with the nature of working-class parenting and the harmful moral influence of the working-class home and neighborhood would remain a central feature of subsequent arguments over compulsory education in the decades following the passage of the Education Act.

The Chartists campaigns for working-class enfranchisement and the mid-century revolutions in continental Europe caused considerable anxiety among British Parliamentarians and made them reluctant to adopt policies that might lead to direct confrontation between agents of the British state and members of the working class. In this political climate, indirect methods of securing universal attendance must have looked attractive to Timbrell and his cohort. Throughout his tract, Timbrell demonstrated an acute awareness of the potential hazards involved in the enterprise of educational compulsion, at one point giving due credit to the "apprehension that the social consequences of a coercive measure would be necessarily dangerous. ${ }^{\prime 34}$ The author also acknowledged that at first glance, the practical effect of universal attendance at the cost of children's labor might seem "contrary to the laws which guide the industry of the 
country, and the conditions of social prosperity." ${ }^{35}$ Timbrell concluded, however, that although coercive measures to secure universal attendance seemed contrary to the broader tenets of Liberalism and might even threaten social stability, ultimately, they were for the greater good of all concerned. "A temporary hardship or injustice," he wrote, "has been originated by almost every great improvement in mechanical progress. That, which may have been wrong to a class, has been beneficial to the majority." 36 The period between 1850 and 1870 witnessed the implementation of indirect educational compulsion of the kind advocated by Timbrell, but only on a very limited scale. In addition to modifications to the laws concerning poor relief, laws regulating the employment of children in factories, workshops, and mines all linked the time allowable for young children's work to minimum levels of education or mandatory minimum periods devoted to education during the work week. ${ }^{37}$ Denison's Act of 1855 , for example, had given the Poor Law Guardians, who administered public welfare funds for family maintenance, the power to require children's regular school attendance as a prerequisite for their parents' receipt of outdoor relief. ${ }^{38}$ The Factory Act of 1833 was the first law that mandated school attendance for child laborers, though even Robert Peel's original Health and Morals of Apprentices Act of 1802 had included a "pious injunction about education." 39 The Act of 1833, besides setting a minimum age for employment (nine years old) and maximum daily hours for the employment of children between the ages of eight and thirteen (nine hours a day, forty-eight hours a week), also set minimum periods of daily education for such child laborers. ${ }^{40}$ If a child was employed daily, three hours of schooling a day were required; if he was employed on alternate days, five hours of schooling a day on the days in between was necessary. 
Initially, these regulations applied only to children working in textile mills and factories, and it was not until 1860 that Parliament extended the Act to other industries. The first Mines Act with an educational provision was the Mines Act of 1860, and it was not until 1867 that children working in shops employing fewer than fifty workers would be required to attend school at all, and then only for a minimum of ten hours a week. ${ }^{41}$ Although most of the Acts passed regulating child labor contained educational provisions, as Gillian Sutherland has pointed out, these measures affected only the relatively small number of children who worked in the specific industries addressed by these laws. ${ }^{42}$ Perhaps the best evidence of national policymakers' preference for indirect rather than direct compulsion could be found in the 1870 Education Act itself, which did not demand compulsory attendance, but left the adoption of such measures to the discretion of the local school boards.

While the idea of universal compulsory education was a fairly new—and not particularly popular — concept in Timbrell's time, the 1850s did witness the practical advent of compulsory education in a limited fashion. Significantly, the origins of educational compulsion lay not in a concern for the education of working-class children per se, but rather as a response to juvenile criminality. Such criminality—or "delinquency," as it was commonly called — was the considered by British policymakers to be a consequence of the morally-degrading influence of the working-class home, the temptations of the street, and the failings of working-class parents. In response, the British government employed a type of direct educational compulsion by using reformatory schools as an alternative to the incarceration of young law-breakers. The Youthful Offenders Act of 1854, which authorized magistrates to send convicted juvenile 
"delinquents" to a reformatory school after a brief prison term, reflected a shift in middleclass attitudes away from support for a justice system that emphasized fear and physical punishment towards one with "a recognizably modern foundation for criminal justice according to which wrongdoers should be re-educated back into the ranks of conformity." ${ }^{43}$ The establishment of reformatory schools as a humane and effective substitute for juvenile imprisonment was embraced with enthusiasm by many Humanitarian reformers. By 1860, fifty-two such schools had been built in England and Wales. ${ }^{44}$

At first, the gulfs in conception, execution, and intention between the reformatory school system and compulsory elementary education seem so wide as to make any comparison untenable. Indeed, the historiographical treatment of these two subjects reinforces this view. Reformatory schooling appears frequently as a topic in discussions of Victorian criminality, but rarely enters the purview of educational historians. By contrast, compulsory schooling, athough it has a significant judicial aspect, is largely treated as an educational issue. This may be because most historians of crime see such statutory mandates as civil rather than criminal issues and prefer to focus on the latter. The categorization of reformatory schools as institutions concerned primarily with crime rather than education mirrors the views that contemporaries held on the issue. As the Home Secretary, Spencer Walpole, insisted:

The vast distinction between Reformatory and primary schools is that the latter are for those who have done no wrong, who seek instruction, and who come and go at their own free will, or at the will of their parents but reformatories are for those sent there under the criminal law by courts 
of justice and compulsorily detained for a definite period and partly no doubt for the purposes of education but partly for correction also. ${ }^{45}$

In 1859 , when the Home Secretary was speaking, this was an accurate appraisal. Primary education, at that time, was almost entirely voluntary. But in the late 1860s, when the implementation of universal primary education began moving from a concept to a concrete policy, the extension of the industrial school system was seriously considered as one possible avenue for the realization of this goal. ${ }^{46}$ The apparent distinction drawn by Walpole and others between the functioning of reformatory schools and other primary schools narrowed considerably after the introduction of compulsory school attendance in the 1870s. Once school boards had adopted a compulsory attendance policy, children could no longer "come and go at their own free will, or at the will of their parents," and ordinary working-class children were, in principle if not always in practice, "compulsorily detained for a definite period."

Changes in the funding and administration of industrial schools in the 1870s further blurred the lines that separated school from prison, both in administration and in purpose. Industrial schools appeared as private ventures around the same time as reformatory schools. In contrast to reformatory schools, which catered to children convicted of serious crimes, industrial schools were meant to serve those who had committed minor crimes or were merely "destitute and unruly." ${ }^{\text {47 }}$ By instilling habits of discipline and order in a closely-monitored environment, they were intended to prevent those children whom local board officials and magistrates thought were at risk of crossing the line into criminality. ${ }^{48}$ Industrial schools, like reformatory schools, usually remained under the direct control of the Home Office rather than being delegated to the 
Education Department, but the 1870 Education Act provided local school boards themselves with the opportunity to construct and fund industrial schools. The London School Board created an Industrial Schools Committee to oversee the work in this area. Perhaps the most prominent expression of the Committee's goal of reforming potential "delinquents" through compulsory school attendance was the refitting of the Shaftesbury as an "Industrial Training Ship" in 1878 , at the cost of $£ 40,000$. 49

Originally created as a substitute to prison for youthful vagrants or lesser delinquents, by the 1870 s, the industrial schools were home to a much broader range of occupants that included not just criminal delinquents, but many children who, under the broad definition of school board authorities and magistrates, were deemed to have been "neglected" by their parents. ${ }^{50}$ In London, at least, this outcome was anything but accidental. A committee made up of LSB members made the initial determination of which cases would be eligable to be sent to industrial schools, although the final decision rested with local magistrates. ${ }^{51}$ As early as 1871 , members of the LSB were arguing for the use of industrial schools as a preventative, rather than punitive, measure against the potential moral degradation of working-class children who might not attend school of their own or their parents' volition. Discussing the discrepancy between boys' enrollment and girls' enrollment in industrial schools, LSB member Benjamin Waugh suggested that "one of the main reasons for the discrepancy was that many of the girls who would otherwise have ended up in Industrial Schools turned instead to prostitution." 52 His proposal to widen the category of children who would fall under the authority of the Industrial Schools Act was greeted with general enthusiasm by the other members of the board. ${ }^{53}$ In discussions of the differences between industrial schools and 
board schools, the focus on financial issues and morality, rather than quality of school environment or education, demonstrates how little difference educational reformers and government officials saw in the overall purpose of these two institutions.

In 1872, a discussion between the Home Secretary and a deputation from the LSB made clear the similarities, in both function and goals, between the industrial school system and compulsory attendance. The question under discussion was whether or not children whose home circumstances and character were acceptable for ordinary board schools were being inappropriately sent to industrial schools instead. The subject itself, in addition to several explicit references by different parties during the discussion, indicated that all parties involved recognized the distinction between the intended nature and constituency of the industrial schools and that of the ordinary board schools. ${ }^{54}$ This distinction, however, emerged as less important, to both the Home Secretary and the LSB members, than the ultimate goal of getting children off the streets and into one sort of institution or another. This point was made most cogently by the Home Secretary when he explained that, "in Stockport, where the compulsory system is in active operation, the School Board have managed to look up all these 'gutter children,' as they have been termed, and have sent them to school. They have, in fact, swept the streets perfectly clean, until none of these children are left behind, and they have not increased the numbers of the industrial schools." ${ }^{.55}$ In this locale, the compulsory attendance laws had made industrial schools almost unnecessary — a perfectly acceptable outcome to him.

The environments of reformatory and industrial schools differed considerably from those of most ordinary board schools, but public authorities and working-class supporters of compulsory education saw all three types of institution as responses to 
ignorance, crime, and poverty among the bottom rungs of Britain's socioeconomic ladder. ${ }^{56}$ Although those involved in social reform and education ardently maintained that the industrial school and the board school were created with different populations in mind, one of the key goals envisioned for both institutions was to get children off the streets and provide them with the perceived benefits of education. Particularly in the cities of nineteenth-century England, the image of the "street arab"- the ignorant, unemployed, and often ill-intentioned juvenile delinquent—was a resonant one in public discourse. ${ }^{57}$ The connection between ignorance and juvenile crime was one that had been established in the minds of reformers by the beginning of the nineteenth century and had gained considerable support in the following decades. ${ }^{58}$ There was a considerable degree of continuity, in purpose if not in character, between the institutions first established by the Youthful Offenders Act of 1854 and those established by the Education Act in 1870. Of particular importance in this regard were industrial schools, which catered not to "criminal" children, but rather to a broader population of those whom state authorities deemed destitute and "neglected." As such, these schools represented an intermediary stage between compulsory education as a substitute for incarceration and compulsory education as a universal obligation.

In the broadest sense, the debate over compulsory education was just a part of the larger discussion that was taking place at all levels of British society over what role government should play in the regulation of working-class private life. Members of the 
London School Board and the broader middle-class public of London faced an ideological dilemma in the issue of educational compulsion. Although most British Liberals, both middle-class and working-class, supported state education, there was a significant amount of dissension within these groups. John Stuart Mill had himself been a strong advocate of compulsory education, arguing that parents who failed to educate their children committed a "double breach of duty, towards the children themselves and towards the members of the community generally, who are all liable to suffer seriously from the consequences of ignorance and want of education in their fellow-citizens. ${ }^{.59} \mathrm{In}$ the latter half of the nineteenth century, moreover, the moral authority of the urban middle-class revolved increasingly around their role as reformers of working-class life and as charitable patrons of the poor. ${ }^{60}$ But the growing middle-class recognition of childhood, when applied to the issue of compulsion, created a dissonance among policymakers, dividing those who prioritized the needs and rights of the parents from those who prioritized the state's duty to protect children.

When the provision of public elementary education rose to the fore of Parliamentary debate in the 1860 s, such tensions were somewhat alleviated by the support for universal compulsory education expressed by many working-class Liberals, and particularly by the most well-organized and politically active of Britain's workingmen, the Trade Unionists and artisans. ${ }^{61}$ The loss of power among Anglican churchmen, the established bastions of local educational authority, as the newly appointed school boards assumed control of elementary schooling, was of serious concern among this cohort. ${ }^{62}$ In this sense, the Education Act of 1870 represented a further erosion of the authority of the Anglican Church and its officers, particularly in 
small towns and the countryside. This process, which opened the door to greater public influence by Dissenters and Nonconformists, had accelerated considerably with the restructuring of local government in the wake of the Great Reform Bill of 1832. By the 1860s, public, nondenominational education and some form of compulsion to ensure its effectiveness appeared to enjoy wide, though not unanimous, support among the population of Britain. ${ }^{63}$ The Reform Act of 1867, which expanded the franchise to include many working-class men, increased support for universal education among many Parliamentarians who feared the damage that an uneducated electorate might wreak on the English political system. ${ }^{64}$ Gillian Sutherland has argued that, by 1870 , there were few people who were willing to oppose all incentives to get working-class children to attend school. Such a stance, at the time, would have been tantamount to opposing education itself, and thus extremely impolitic. ${ }^{65}$

In contrast to the general consensus that some level of legal enforcement would be necessary to insure that the children of the poorest parents attended school, Parliamentary Liberals' views on direct compulsion (i.e. legal prosecution and fines for non-attendance) were far from unanimous. W.E. Forster, the Liberal sponsor of the Education Act of 1870, argued for the necessity of direct compulsion, and the more leftleaning members in the Liberal Cabinet pushed for sterner measures than the Act - which permitted but did not require school boards to use direct compulsion - mandated. ${ }^{66}$ Such efforts were defeated, however, by moderate Liberals who supported personal autonomy and feared the dire consequences of "demoralizing" the poor through social legislation. ${ }^{67}$ As John Walter, a Liberal back-bencher, declared, "the loss of self-respect involved in the notion that parents were so insensible to their duties to their children as to require the aid 
of the Legislation to compel them to discharge those duties would be greater than any gain to be derived by the limited number of persons to whom such compulsion would be applied." 68 Although he presided over his government's passing of the Education Act of 1870, W.E. Gladstone's view of direct compulsion itself is unclear. ${ }^{69}$ The rhetoric of the debates over compulsion reflected these tensions among Liberals, the conflicted middleclass views of state intervention in general, and the conviction among the most vocal and politically organized of the labor aristocracy that only stern legal enforcement would insure the education of the most "idle and vicious."70 The most common disputes in the public forum pitted the importance of parental "rights" and "liberty" against parental "duty" and the good of the children themselves.

A clear articulation of the typical arguments against compulsory education appeared in an 1875 tract, Compulsory Education as Opposed to the Liberty of the Citizen, which was published in London. In the tract, the anonymous author-who explicitly allied himself with the Conservative party and expressed strong support for the educational work of the Church of England—railed against what he called the "enlightened despotism" of the government:

Every year of late, measures in restrictions of personal freedom have been introduced and carried into effect, all enforcing compulsion in some form for definite objects, such as vaccination, the inspection of immoral women \&c., and every year restrictive measures are proposed with a view of carrying into action the whims and crochets of individuals, classes, or associations. But for the first time in political life restrictive 
laws are brought into operation, with reference to the daily management of the family by the parent. ${ }^{71}$

In his criticism of educational compulsion, the author both linked the new project to past efforts of government compulsion in other areas life and also identified compulsory education as a distinctly more insidious measure of reform than those that had preceded it. In particular, the author was keen to point out that the enforcement of compulsory school attendance violated the sanctity of the home, a locale whose independence from outside interference was considered by many among the middle class to be a cornerstone of the English concept of liberty. ${ }^{72}$ Lamenting the violation of this ideal, the author wrote, “in former times, the Englishman's proud boast was that his house was his castle. This can no longer be said, for the poor man at any rate." ${ }^{, 73}$

The argument that the imposition of compulsory attendance represented an unacceptable form of tyranny was a common one among those who wrote in opposition to the practice. In his 1904 retrospective, LSB chronicler Hugh Philpott explained that such an argument had been particularly popular among politicians, and that its use encouraged resistance to compulsory methods by working-class parents. ${ }^{74}$ One author to the School Board Chronicle labeled the practice of educational compulsion a "cruel and tyrannical use of power," and implied that the implementation of such a system upon the working class could have the most disastrous social consequences. ${ }^{75}$ After first bemoaning the granting of the franchise to the working classes by the Conservatives in 1867 , an act which this author claimed was done not in a spirit of philanthropy, but rather "because certain parties required to be kept in office," the author warned, "shall we fall 
into the lamentable error of trying to tame [the working-class man] by force? Heaven forbid! — or when he learns his strength we shall find no taming has been done; and he will have no mercy on those who in their time of power had none on him.."76 The idea that compulsory education was a "tyranny" that contradicted the rightful "liberty" of the individual was, moreover, one which enjoyed considerable longevity, as evidenced by Ernest Pomeroy's 1909 work, The Education Tyranny, in which the author posed the rhetorical question to readers: "the compulsion is wrong because to each man his own opinion is the right one, and who are you to interfere with him?"77

Ultimately, for Philpott, Pomeory, contributors to the School Board Chronicle, and the anonymous author of Compulsory Education, writing across the span of the LSB's tenure and beyond, the legal compulsion of parents, rather than the possible need and value of education for working-class children, was the lynchpin of their arguments. This focus on the relationship between the state and parental authority bridged the gap between those who saw education in social terms and those who utilized it as a political lever in the ongoing contest between Liberals and Conservatives. Gender concerns were also a central concern for the author of Compulsory Education, who argued that the state intervention in private life, most reprehensibly supported by a Liberal administration in the 1870s, constituted a direct attack on male authority over family and household. With compulsory education, he asserted, "the state, as represented by the tyrannical majority in parliament, has usurped the natural authority of the father, who is no longer treated as a person with independent and special privileges as a free citizen of a free state, but simply as one of millions of units whose sole use is to support the vast fabric of the state." ${ }^{78}$ To make matters worse, the author wrote, the structure of the new laws, which held the 
father as the sole party responsible for a child's school attendance and thus liable to penalty under legal prosecution for a child's absence from school, sabotaged male control over the household. In particular, the author claimed that the police magistrates who prosecuted school attendance cases were "ever disposed to ignore the authority of husbands and fathers, and to encourage insubordination of wives and children." ${ }^{19}$ The scenario that the author presented to readers was one in which children, with the aid of their mothers, connived to play truant from school, and the poor, hapless, working father was then victimized by the state for his family's behavior. The terrible end result of this system, the author wrote, was that "the natural rights of the parent, in other words of the father (for in the vast majority of cases the mother is held totally irresponsible in matters of family education as in other things), have now been abrogated, and the child is taught that his duty of obedience and subordination is not due to his father but to the state." ${ }^{\prime 80}$

For the author of Compulsory Education as Opposed to the Liberty of the Citizen, educational compulsion was a barometer for the declining rights of the individual in relation to the increasing influence of the state in the idealized "private life" of home and family. As the author wrote of the worsening situation for working-class men, "so far from his house being a 'castle' he finds that it is never free from the intrusion of insolent officials." ${ }^{81}$ The form and content of the author's argument indicate how readily the public discourse over compulsory education could be adapted to the broader political climate of the time. In the context of the new laws on married women's property rights and the increasing role of the courts in the adjudication of marital disputes, the author could hardly have struck a more effective chord with male readers than by accusing magistrates of sabotaging male authority within the family. ${ }^{82}$ The author's vilification of 
Liberal politics and his jaded portrayal of women's domestic strategies, in conjunction with his support of Anglican educators and his chiding of Conservatives for abdicating "their natural position as protectors of the humbler classes," give further indication that politically-minded middle-class men were the intended audience of the piece. ${ }^{83}$ With this cohort in mind, it was easy for the author to map the arguments over educational compulsion onto the broader political conflict between Liberals and Conservatives and to employ the issue as a goad in the ongoing competition for votes.

$* * *$

In contrast to those who opposed direct compulsion, the system's supporters, both in the LSB and among the broader public, tended to argue that the rights of parents to liberty and authority over their families were of secondary consideration to the rights of children themselves. Those who defended compulsory attendance also argued that without its implementation, the entire public educational system would function neither effectively nor efficiently. Underlying these arguments, however, lay both a deeper moral assumption concerning the character of working-class parents and, for many, a commitment to the new ideology of "child welfare." The proponents of educational compulsion in London, drawn largely from the middle class, argued that educational authorities themselves were an incontrovertibly positive force, both in moral influence and in their practical improvement of working-class life. Education officials, the supporters of compulsion argued, had both the right and the duty to correct the failings of immoral working-class parents. Without the intercession of education officials, they 
argued, immoral parents would fill the streets with "hooligans" and fill the factories and workshops with oppressed and exploited child laborers.

The conviction among educational reformers, such as Benjamin Waugh and his allies in the LSB, that state intervention was the only effective answer to the most serious cases of parental neglect was a central tenet of their arguments. This support for state intervention was strongest on the issues of education, health, employment, and physical abuse. ${ }^{84}$ As one author wrote to the editor of the School Board Chronicle in 1871, relating compulsory education to the other social reforms that had preceded it, "there is nothing very remarkable or novel in the idea of enforcing certain duties on those who are too ignorant or too vicious voluntarily to perform them." 85 In order to defend state interference in the home, the members of the LSB and those in the wider public who supported compulsory education articulated a moral stance that placed the good of the child and parents' duty to them and to the good of the nation above individual rights and the sanctity of parental authority in the home. The members of the LSB who drew up the initial bye-laws relating to compulsory attendance specifically articulated this position. ${ }^{86}$ This argument was used as a justification for compulsion by members of other school boards across England. As one member of the Hull School Board explained in his proposal to form an attendance bye-laws committee, "he found it difficult to reconcile himself to the principle of compulsion; but the results of the indolence of some parents, which was inexcusable, and of the selfishness of others, which was utterly unjustifiable, had convinced him that it was necessary to resort to it in the interests of both the children and the State." 87 
The arguments that children had inherent rights that superseded parental authority and that the protection of these rights was a justification for state intervention, however, would not reach full expression until the first cohesive campaign against parental cruelty to children began in the 1880s. As popular as the notion of children's rights was among school board members in the 1870 s, it is not surprising that some of the most influential figures in the anti child-cruelty movement of the following decade had also been members of the first school boards and staunch advocates of compulsory attendance. Benjamin Waugh was himself the founder of the London Society for the Prevention of Cruelty to Children. Waugh's experiences with working-class parents had reinforced his belief that state intervention was an essential counter to parental neglect. ${ }^{88}$

The continuity between the two projects, the first to secure compulsory attendance and the second to prevent cruelty to children in the home, was made even clearer when the founder of the Liverpool SPCC publicly declared that his organization should look work of the school boards for their lessons in how to confront "the great sea of human cruelty and neglect" faced by the LSPCC ${ }^{89}$ The public arguments in favor of educational compulsion, the experiences of reformers on the LSB, and the discourse of morallydegraded working-class parenthood that justified direct intervention in working-class family life were all essential precedents to the anti child-abuse campaigns of the 1880 s. But even beyond the connections of ideology and personnel between the two campaigns there lay a profoundly practical link. Education workers were among the most important sources of information to the SPCCs in their initial years of operation. Liverpool school board officials and schoolteachers, for example, were responsible for reporting $15.5 \%$ of 
all cases handled by the Liverpool SPCC from 1884-1885, a higher percentage than the officers of the society themselves reported in the same period. ${ }^{90}$

$$
* * *
$$

The debates over direct compulsion and the justifications put forward by the supporters of this policy reflected the underlying class biases of the board members. The public discourse over the use of compulsory methods also demonstrated that educational compulsion was merely one aspect of a much broader political debate taking place in British society over the expanding role of the state in private life and its impact on the liberty of the individual. The implementation of compulsion is therefore best seen in the broader context of the state's growing presence as an allegedly moral force in the lives of the working class, the persistence of paternalism as a governing principle in social policy, the inconsistencies and contradictions of Liberal ideology, and the increasing tendency among some policymakers and elected officials to prioritize the good of a national community in which membership was defined by duties and obligations over the rights and liberties of individuals within that community.

The precedent for the use of compulsory schooling as a moral counter to the negative influence of working-class homes and neighborhoods, and as an ameliorative for those children who had thus far showed little promise of contributing positively to society, had already been established by reformatory and industrial schools. Likewise, the use of social welfare practices as a means to destabilize the working-class family was concurrent with the broader deployment of charity that had preceded the passing of the 
1870 Education Act. ${ }^{91}$ For the members of the London School Board, coercion, though distasteful, was a necessary precursor to insure the relocation of working-class children from the moral vacuum of the home and street to the more salubrious environs of the classroom. Most LSB members genuinely favored the education of London's workingclass children, but their preoccupation with the overall moral state of the working-class family and the future of the nation took precedence. Although the policies of the LSB were often expressed in terms that drew legitimacy from the growing child-welfare movement of the later nineteenth-century, the laws on compulsory education were debated and adopted by those who were often more concerned with reforming workingclass parents or with insuring that their children did not follow their parents' immoral ways than they were with education itself.

${ }^{1}$ The Independent, 16 October 2006. Quoted subsequently in the New York Times, Alan Cowell, "For Multiculturalist Britain, Uncomfortable New Clothes,” 22 October 2006.

2 Thomas Gautrey, “Lux Mihi Laus”: School Board Memories (London: Link House, 1937), 13.

${ }^{3}$ The Forster Act mandated the election of local "school boards" which would oversee the entire educational apparatus in specific locales.

${ }^{4}$ Gautrey, Lux Mihi Laus, 9-11. Gautrey lamented the replacement the "democratic" LSB with the merely "bureaucratic" LCC.

${ }^{5}$ Ibid.

${ }^{6}$ It should be noted that a significant proportion of these convictions were for repeat offenders. Annual Reports of the London School Board, 1887-1904. [London Metropolitan Archives]. Comprehensive statistics on summonses and convictions are only available beginning in 1887 . The LSB had been bringing 
cases before the courts since 1872, however, at the rate of several thousand a year. In the first six months of 1880, for example, the LSB issued 5,174 court summonses to parents for violations of the attendance bye-laws. Minutes of the Bye-Laws Committee of the London School Board, 13 Oct. 1880, 244 [LMA]. ${ }^{7}$ Annual Reports of the London School Board, 1887-1904.

${ }^{8}$ Gautrey wrote that, in one incident, "our school board visitor [reported] that one morning on his way to the school a dead cat was dropped upon him from a first-floor window.” Gautrey, Lux Mihi Laus, 35.

${ }^{9}$ Ernest Pomeroy, The Education Tyranny: The Education System Examined and Exposed, Together with Practical Aids for Persecuted Parents (London, 1909) [British Library].

${ }^{10}$ In 1763, Prussia, under Frederick II, became the first major European nation state to make elementary education mandatory. The first U.S. state to adopt compulsory school attendance was Massachusetts, which did so under the leadership of Horace Mann in 1852. Austria introduced mandatory education in 1874. France adopted the policy in 1881 with the Jules Ferry Laws.

${ }^{11}$ Pavla Miller, "Historiography of Compulsory Schooling: What is the Problem?" History of Education 18 (1989): 123-144.

${ }^{12}$ Carolyn Conley, The Unwritten Law: Criminal Justice in Victorian Kent (New York: Oxford University Press, 1991), 134.

${ }^{13}$ Nigel Middleton, "The Education Act of 1870 as the Start of the Modern Concept of the Child," British Journal of Educational Studies 18 (1970), 173; Harry Hendrick, Child Welfare: England 1872-1989 (London: Routledge, 1994), 30-32; Hugh Cunningham, Children and Childhood in Western Society Since 1500 (London: Longman, 1995); Phillip Aries, Centuries of Childhood: A Social History of Family Life (New York: Knopf, 1962).

${ }^{14}$ A similar argument would be made in the late nineteenth-century campaign against parental cruelty to children. George Behlmer, Child Abuse and Moral Reform in England, 1870-1908 (Stanford: Stanford University Press, 1982), 16.

15 This notion, however, has been strongly challenged by recent studies of childhood and parental practice, which have argued that working-class parents, mothers in particular, were deeply invested in their children and went to great lengths to nurture and protect them to the best of their ability. Ellen Ross, Love and Toil: Motherhood in Oucast London (New York: Oxford University Press, 1993), 166-94. 
${ }^{16}$ J.S. Hurt, Elementary Schooling and the Working Classes 1860-1918 (London: Routledge 1979), 3. For a broader look at state involvement in the "private" lives of the working class, see George Behlmer, Friends of the Family: The English Home and Its Guardians, 1850-1940 (Stanford: Stanford University Press, 1998).

${ }^{17}$ For a broader discussion of the redefining of "self" in relation to "the social" among both the middle class and the working class, and for the relationship of this dynamic to the expansion of government authority, see Patrick Joyce, Democratic Subjects: The Self and the Social in Nineteenth-Century England (Cambridge, UK: Cambridge University Press, 1994), 17.

${ }^{18}$ W.P. McCann, "Trade Unionists, Artisans and the 1870 Education Act," British Journal of Education Studies 18 (1970),

${ }^{19}$ Nigel Middleton, “The Education Act of 1870,” British Journal of Educational Studies 18 (1970), 168.

${ }^{20}$ Matthew Arnold spoke there annually. Nicholas Murray, A Life of Matthew Arnold (New York: St. Martin's Press, 1997), 74.

${ }^{21}$ Frederick Timbrell, Compulsory Education (London, 1855), 3.

${ }^{22}$ Ivy Pinchbeck and Margaret Hewitt, Children in English Society, vol. 2: From the Eighteenth Century to the Children Act 1848 (London: Routledge, 1973).

${ }^{23}$ Timbrell, Compulsory Education, 3.

${ }^{24}$ Hendrick, Child Welfare, 23. Peter Mandler has found a similar dynamic in the function of Victorian charity as applied to the family as a whole. According to him, the fundamental aim of charity in many nineteenth-century cities was the "recasting of the working-class family in a middle-class mold." Peter Mandler, ed., The Uses of Charity: The Poor on Relief in the Nineteenth-Century Metropolis (Philadelphia: University of Pennsylvania Press, 1990), 26.

${ }^{25}$ Timbrell, Child Welfare, 3.

${ }^{26}$ Ibid., 12.

${ }^{27}$ See Ross, Love and Toil, 23-25, and Behlmer, Friends, 74-128.

${ }^{28}$ In the first half of the nineteenth century, providing social service to the working class had become an essential aspect of the establishment by the middle class of their claim to moral and political authority. 
Eileen Yeo, The Contest for Social Science: Relations and Representations of Gender and Class (London:

Rivers Oram, 1996), 58-60.

${ }^{29}$ Timbrell, Compulsory Education, 12. The Inspectors were responsible for examining and certifying the Industrial and Reformatory Schools were established, at public expense, in the years prior to the Education Act of 1870. They would expand their purview to include the new schools of the public elementary education system after the passing of the Act.

${ }^{30}$ Ibid., 8 .

${ }^{31}$ Ibid., 8-9.

${ }^{32}$ Ibid., 15.

${ }^{33}$ Ibid.

${ }^{34}$ Ibid., 9.

${ }^{35}$ Ibid.

${ }^{36}$ Ibid.

${ }^{37}$ Gillian Sutherland, Policy Making in Elementary Education 1870-1895 (London: Oxford University Press, 1973), 115-117.

${ }^{38}$ Ibid., 115. "Outdoor relief" referred to the granting of welfare funds without first requiring the family to surrender their private residence and enter a government-run "workhouse."

${ }^{39}$ Ibid., 116.

${ }^{40}$ Ibid.

${ }^{41}$ Ibid.

${ }^{42}$ Ibid., 117.

${ }^{43}$ Geoffrey Pearson, Hooligan: A History of Respectable Fears (London: Macmillan, 1983), 179.

${ }^{44}$ J. Stack, "Interests and Ideas in Nineteenth-Century Social Policy: The Mid-Victorian Reformatory School," Journal of Educational Administration and History 14 (1982), 36.

${ }^{45}$ Spencer Walpole in Martin Wiener, Reconstructing the Criminal: Culture, Law, and Policy in England, 1830-1914 (Cambridge, UK: Cambridge University Press, 1990), 137.

${ }^{46}$ Middleton, "The Education Act of 1870," 170-1. 
${ }^{47}$ J. J.Tobias, Crime and Industrial Society in the Nineteenth Century (New York: Schocken, 1967), 214. Alan W. Jones, Lyulph Stanley: A Study in Educational Politics (Waterloo, Ontario: Wilfred Laurier University Press, 1979), 30.

${ }^{48}$ Tobias, Crime and Industrial Society, 214. Behlmer, Child Abuse, 11.

${ }^{49}$ Jones, Lyulph Stanley, 31.

${ }^{50}$ For the use of industrial and reformatory Schools as solutions to the problem of the Victorian "Street Arab," see Behlmer, Child Abuse, 11; Anna Davin, Growing Up Poor: Home, School, and Street in London 1870-1914 (London: Rivers Oram, 1996), 163-4.

${ }^{51}$ The School Board Chronicle, Feb. 3, 1872, 369 (hereafter Chronicle).

${ }^{52}$ Chronicle, May 6, 1871, 364.

${ }^{53}$ Ibid.

${ }^{54}$ At one point, the Home Secretary insisted that "it is only the criminal class that it was intended to be dealt with under the Industrial Schools Act.” Chronicle, Feb. 3, 1872, 369.

${ }^{55}$ Ibid.

${ }^{56}$ McCann, "the 1870 Education Act," 147.

${ }^{57}$ Heather Shore, Artful Dodgers: Youth and Crime in Early Nineteenth-Century London (Rochester, NY:

Royal Historical Society/Boydell, 1999), 1-7; Peter King, "The Rise of the Juvenile Delinquency in England, 1780-1840: Changing Patterns of Perception and Prosecution," Past and Present 160 (1998): 116166; Stephen Humphries, Hooligans or Rebels? Oral History of Working Class Childhood and Youth, 1889-1939 (Oxford: Blackwell, 1981); Pearson, Hooligan.

${ }^{58}$ Margaret May, “Innocence and Experience: The Evolution of the Concept of Juvenile Delinquency in the Mid-Nineteenth Century,” Victorian Studies 17 (1973): 20.

${ }^{59}$ John Stuart Mill, Principles of Political Economy, ed. Jonathan Riley (Oxford: Oxford University Press, 1994), 339.

${ }^{60}$ Behlmer, Friends, 31-73 and Child Abuse; Ross, Love and Toil, 11-26; Pat Thane, Foundations of the Welfare State (New York: Longman, 1982); Stefan Petrow, Policing Morals: The Metropolitan Police and the Home Office 1870-1914 (Oxford: Clarendon Press, 1994). 
${ }^{61}$ McCann, "the 1870 Education Act," 137; Eugenio Biagini, Liberty, Retrenchment, and Reform: Popular Liberalism in the Age of Gladstone, 1860-1880 (Cambridge, UK: Cambridge University Press, 1992), 202.

${ }^{62}$ Biagini, Popular Liberalism, 204-205.

${ }^{63}$ Sutherland has pointed, in particular, to opposition from those who employed "cheap child labour."

Sutherland, Elementary Education, 118.

${ }^{64}$ Walter Arnstein, Britain Yesterday and Today, 1830 to the Present, $8^{\text {th }}$ edition (Boston: Heath, 2001), $130-1$.

${ }^{65}$ Sutherland, Elementary Education, 118.

${ }^{66}$ Ibid., 120.

${ }^{67}$ Middleton, “The Education Act of 1870," 175-6

${ }^{68} 3$ Hansard cxcic., col. 492, quoted in Sutherland, Elementary Education, 120.

${ }^{69}$ Eugenio Biagini and Alastair Reid, Currents of Radicalism: Popular Radicalism, Organized Labour, and Party Politics in Britain, 1850-1914 (Cambridge, UK,: Cambridge University Press, 1991), 11; Sutherland, Elementary Education, 120-121.

${ }^{70}$ This last was the view articulated by Robert Applegarth, a spokesman for Joseph Chamberlain's National Education League, a Nonconformist and Radical working-man's association formed in Birmingham in 1869 to promote the adoption of universal education legislation. Monthly Paper 7 (June 1870), cited in McCann, "The 1870 Education Act," 147.

${ }^{71}$ Anon., Compulsory Education as Opposed to the Liberty of the Citizen (London, 1875), 6 [British Library].

${ }^{72}$ See Behlmer, Friends, 22-24.

${ }^{73}$ Anon., Compulsory Education, 7.

${ }^{74}$ Hugh Philpott, London at School: The Story of the School Board, 1870-1904 (London: T. Fisher Unwin, 1904), 27.

${ }^{75}$ Chronicle, Sept. 28, 1871, 213.

${ }^{76}$ Ibid.

${ }^{77}$ Pomeroy, The Education Tyranny, 17.

${ }^{78}$ Anon., Compulsory Education, 6. 
${ }^{79}$ Ibid., 8.

${ }^{80}$ Ibid., 10-11.

${ }^{81}$ Ibid., 10.

821870 saw the passing of the Married Women's Property Act, which gave wives limited control over their own earnings. In 1878, the passing of the Matrimonial Causes Act made provisions for the financial support of abused wives who had been granted legal separations from their spouses. A.J. Hammerton, Cruelty and Companionship: Conflict in Nineteenth-Century Married Life (New York: Routledge, 1992), 83-108.

${ }^{83}$ Anon., Compulsory Education, 12.

${ }^{84}$ Behlmer, Child Abuse, 15-16; Ross, Love and Toil, 24.

${ }^{85}$ Chronicle, April 22, 1871, 312.

${ }^{86}$ Chronicle, July 1, 1871, 200.

${ }^{87}$ Chronicle, April 29, 1871, 337.

${ }^{88}$ Behlmer, Child Abuse, 61.

${ }^{89}$ Ibid., 54.

${ }^{90}$ Officers of the SPCC accounted for $14.4 \%$ of all cases reported. Ibid., 72.

${ }^{91}$ Lynn Hollen Lees, "The Survival of the Unfit: Welfare Policies and Family Maintenance in NineteenthCentury London," in Mandler, The Uses of Charity, 81. 